The Journal of Society and Media, April 2021, Vol. 5(1) 173-198

https://journal.unesa.ac.id/index.php/jsm/index

E-ISSN 2580-1341 and P-ISSN 2721-0383

Accredited KEMENRISTEK/ BRIN No.148/M/KPT/2020

DOI: 10.26740/jsm.v5n1.p173-198

\title{
Repressive Political Communication through Legal Products to Preserve Ideology of Jokowi's Government
}

\author{
Oni Dwi Arianto $^{1 *}$, Anang Sujoko², Agus Wahyudi ${ }^{3}$ \\ ${ }^{1,2}$ Faculty of Social Science and Political Science, Universitas Brawijaya, Malang, \\ Indonesia \\ Email: oni.bojonegoro@gmail.com \\ Email: anangsujoko@ub.ac.id \\ ${ }^{3}$ Faculty of Teaching and Education Science (FKIP), Universitas NU Surabaya, \\ Surabaya, Indonesia \\ Email: aguswahyudi@unusa.ac.id
}

\begin{abstract}
The fundamental value of democracy is civil liberties to express an opinion, assembly, and organization. Data from various institutions observing Indonesian democracy show that since Jokowi's leadership, Indonesia has had problems with civil liberties, from previously free to partly free, thus falling into the flawed category of democracy. The decline in civil liberties was triggered by the Jokowi administration's repressive political communications manifested in the form of repressive legal products. These repressive legal products are used to suppress critical opposition groups who are at odds with the Jokowi administration. This study uses a critical paradigm based on qualitative methods that utilize the theory of Political Discourse Analysis (PDA). The research objective is to reveal the various repressive legal products of the Jokowi administration as well as to explain the context, history, power, and ideology behind the production of these repressive laws. The object of study related to repressive legal products is limited to online news published by media verified by the Press Council. The results of the study concluded that the Jokowi administration presented repressive legal products to perpetuate power and smooth the implementation of capitalist neoliberal ideology.
\end{abstract}

Keywords: repressive political communication, legal products

Paper type: Research paper

*Corresponding author: oni.bojonegoro@gmail.com

Submited: 2021-02-26; Accepted: 2021-04-28; Published: 2021-04-29

Cite this document: Arianto, Oni Dwi, Anang Sujoko, Agus Wahyudi. (2021). Repressive Political Communication through Legal Products to Preserve Ideology of Jokowi's Government. The Journal of Society and Media, 4(2), 173-198. DOI: 10.26740/jsm.v4n2.p173-198. 


\section{INTRODUCTION}

Data on civil liberties during the presidency of President Joko Widodo has decreased. The Freedom House release states that there has been a decrease in the civil liberties index from free in 2006 to 2013 to partly free from 2014 to the present (Repucci 2020). Index from Freedom House (scale 0-10) is also used as a basis for distinguishing democratic or authoritarian countries. The Economist Intelligence Unit (EIU) even assesses Indonesia's democracy in the category of flawed democracies. Worsening civil liberties in democratic countries because leaders implement minimalistic democracy (Møller and Skaaning 2013) because Jokowi is the type of developmentalist leader (Warburton 2016) who is more concerned with investing than implementing the substitution of democracy.

The decline in civil liberties in Indonesia was also confirmed by the Central Statistics Agency (BPS) in its 2020 report, Lokataru, the Indonesian Legal Aid Foundation (YLBHI), Safenet, a survey by the Indonesian Survey Circle (LSI) and Saiful Mujani Research and Consultant and (MSRC) in 2019, as well as a survey of the Institute for Economic and Social Research, Education and Information (LP3ES) and Indonesian Political Indicators (IPI) in 2020.

The cause of the decline in the civil liberties index in Indonesia is due to the emergence of legal products characterized by: multiple interpretations of the Law on Electronic Information and Transactions (ITE), the use of political authority to dissolve community organizations (Ormas) which are deemed to disagree with Pancasila, discrimination of minority groups, violence in Papua and West Papua, to the arrest of demonstrators and activists. Repressive political communication aims to discredit a person, group, or organization because of differences in political views (Goldstein 1983 in (Davenport 1995).

Meanwhile, (Davenport 2007) sees repressiveness as the regime's response to domestic threats. Furthermore, Davenport explained the reasons for political leaders to use a repressive approach are: first, they do not have a viable alternative to exercising political control. Second, they will not be affected or the consequences of the choice of repressive measures. Third, there are generally no effective mechanisms to counter or check the power of coercive authority in the government.

The government regime in Indonesia before Joko Widodo also implemented repressive political communications. Soekarno implemented a 


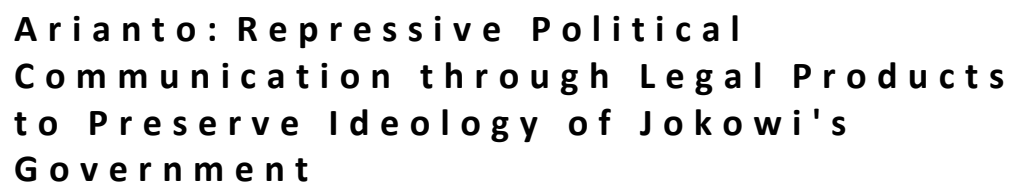

guided democracy system by co-opting the new managerial class (priyayi) so that there was an authoritarian centralization (Fakih 1981). Soekarno's centralization and authoritarianism grew stronger towards the end of his leadership period. The impact of Soekarno's guided democracy application was the dissolution of the Indonesian Socialist Party (PSI) and the Masyumi Party in 1960 (Fakih 1981).

When the government regime changed to Orde Baru with Suharto as the central patronage, the state bureaucracy system was controlled by utilizing the legitimacy of the DPR and supported by military power as bureaucratic legitimacy and authority (Fakih 1981). Soeharto's authoritarian system with its repressive political communications has made an impression on the history of the Indonesian nation for approximately 32 years. Reformasi overthrew Soeharto but the euphoria was short lived.

After the reformation, the community hopes for Jokowi's figure because Jokowi as a leader not from the party's elite oligarchy ((Mietzner 2015) and not from the military (Muhtadi 2015). He was born out of populism (Hamid 2014) although the 2014 presidential nomination was attacked by the tabloid Obor Rakyat of the People as Chinese descent (Tyson and Purnomo 2017) and pro-PKI (Barata and Simanjuntak 2019).

The public's trust was eventually hurt because Jokowi still couldn't be separated from the elite oligarchy. It happened because the expensive political system forces prospective nation leaders to collaborate with nominating oligarchs (Winters 2013). But Jokowi is a smart politician to take the momentum to win the sympathy of the people. It was proven from Solo with his phenomenal ESEMKA car (Fauzi 2018). Walaupun ada kesepakatan antar elite (Ferazia, Prayudi, and Afifi 2020) but Jokowi is still seen with grassroots.

The democratic system adopted by Indonesia has apparently not eliminated the repressive behavior of the state, even though the law explicitly states the order to guarantee civil liberties in opinion, assembly and association. The Indonesian nation has the 1945 Constitution Article 28E Paragraph (3) states that everyone has the right to freedom of association, assembly and expression. Apart from the 1945 Constitution, the Indonesian nation also has a legal basis in the form of MPR Decree Number XVII / MPR / 1998 Article 19 which states that, 
"Everyone has the right to freedom of association, assembly and expression of opinion". These two basic foundations are spelled out in the operational law, namely the Law of the Republic of Indonesia Number 9 of 1998 concerning Freedom to Express Opinions in Public.

The existence of legislation in democracy in Indonesia that has guaranteed civil liberties is not directly proportional to the improvement in guarantees of civil liberties. During the Jokowi administration, the trend of the civil liberties index consistently declined due to the issuance of laws, perppu and Joint Decree (SKB) which limited civil liberties and tended to be repressive. Repressive political communication with the issuance of repressive legal products that limit civil liberties will be taken said in this research. By utilizing the Political Discource Analysis (PDA) theory, researchers will find out what repressive legal products issued by the Jokowi government and why these can arise in relation to context, history, power, and ideology that influence the emergence of repressive legal products. With its power, the regime will carry out ideology (the fundamental belief of the group, (Dijk 2011) supported by conditioned legal products.

The use of PDA theory in this study received many inspiration from Teun van Dijk, Norman Fairclough, and Wodak. PDA integrates arguments in CDA (Fairclough, 2012). Therefore, the details of the important characteristics of CDA, namely action, context, history, power, and ideology (van Dijk 1997); (Wodak 2009) are also important characteristics of PDA by adding political words to each of these characteristics so that it becomes political action, political context, political history, political power, and political ideology.

The framework in this study begins with the pattern of normal, reciprocal, neutral, and balanced political communication relationships between the ruling regime chosen through general elections and organizations, community groups or individual pressures of the government (rulers) (Lillaker 2006). The pattern of reciprocal relations that occurs in the Lilleker chart also does not explain the tools or media used to bridge political communication. Lilleker still sees the media as a neutral channel and the public as the object of political communication. 
Arianto: Repressive Political

Communication through Legal Products

to Preserve Ideology of Jokowi's

Government

Table 1.

The Level of Political Communication Darren G. Lilleker tahun 2006

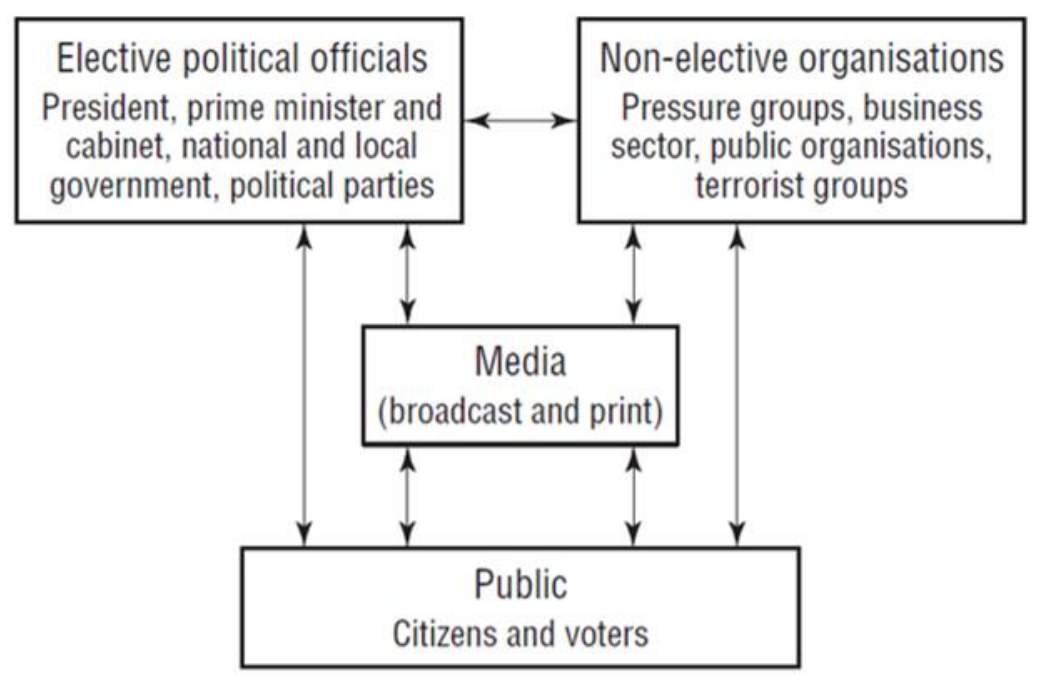

Meanwhile, in the study of the Jokowi administration's repressive political communication, it shows that the flow of political communication is carried out by means of or through the media of legal products from the ruling regime to critical opposition groups. The nature of communication is unidirectional, not neutral, and no longer balanced. Superior control is in the ruling regime to suppress critical opposition groups. The media and the public have taken sides in the ruling regime or critical opposition groups.

Table 2.

Repressive Political Communication through Legal Products

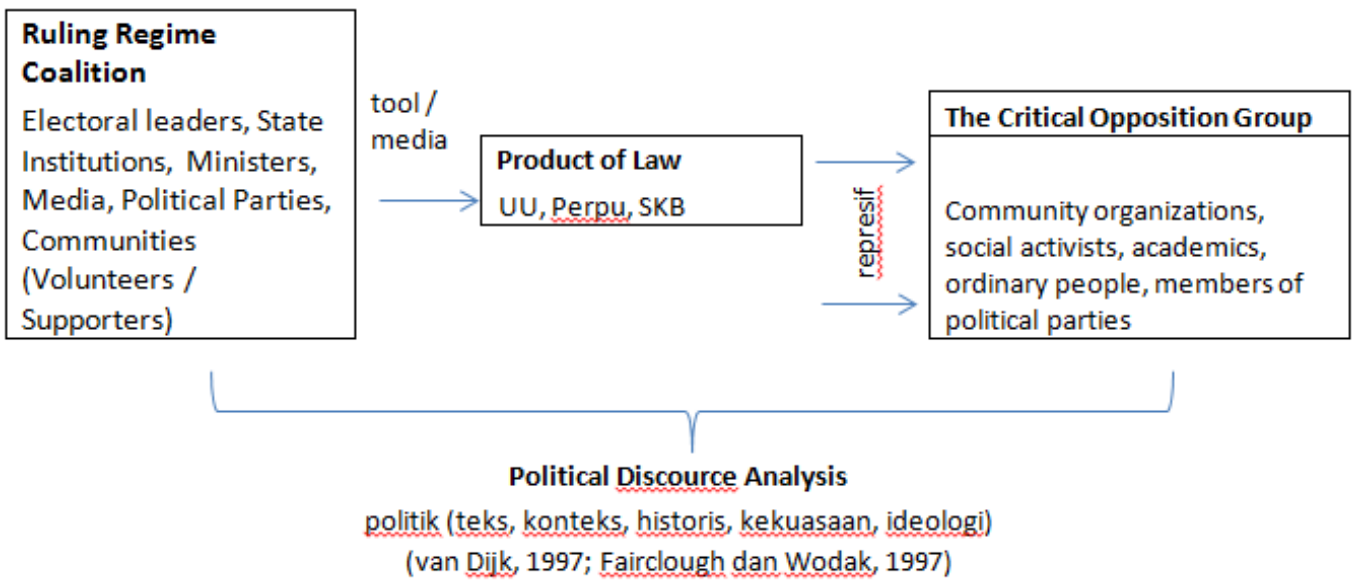


The novelty of this research is that the relationship of political communication that is built between the ruling regime (Jokowi's administration) and critical opposition groups run in one direction (not reciprocity), is not neutral, and is not balanced because it is related to the tools or media used in the form of legal products that are binding and used to oppress opposition groups. The Jokowi administration's repressive political communication against critical opposition groups is the result of this study.

\section{METHOD}

Research with this critical paradigm approach was conducted using qualitative methods. The data was taken from various texts that have been published on the internet and online media during the first period of President Jokowi's administration in 2014-2019 and part of the second period of President Jokowi's administration in 2019-February 2021. The chosen online media is online media that is credible and responsible under the Law. Law Number 40 of 1999 concerning the Press and Regulation of the Press Council Number 3 of 2019 concerning Standards for Press Companies. Some of the requirements for a press company are: 1. Legalized as a PT or other form regulated by law. 2. Received approval from the Ministry of Law and Human Rights. 3. Announcing the name, address, editorial contact, and the person in charge of the media. 4. The person in charge of the wajid editorial staff has the competence of the main journalist. 5 . The editor in charge is not a political party administrator. 6. Have a capital of at least IDR 50,000,000 and the ability to carry out company activities for at least 6 months.

With the announcement from the Press Council, it was easier for researchers to determine which online media was used as the source of data in this study because its validity, credibility, and accountability had been tested. In addition, to ensure that the news on several online media is reliable information, the researcher cross-checks between media that have received the legitimacy of the Press Council so that the information that the researchers take is mu'tabar (calculated and trusted) information from various online media information.

Media coverage which is used as a source in this research is news from kompas.com (administrative and factual verified by the Press Council on 17-06- 


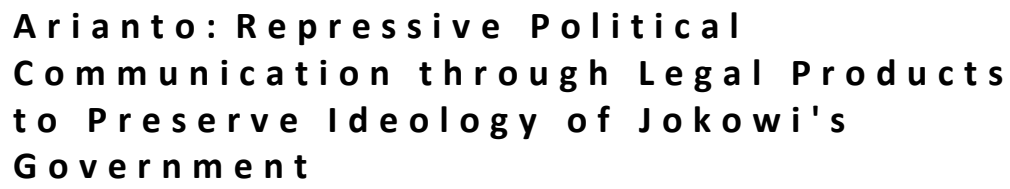

2019), detik.com (administrative and factual verified by the Press Council on 0409-2018) , kumparan.com (administrative and factual verified by the Press Council on 04-09-2018), tempo.co (administrative and factual verified by the Press Council on 04-09-2018), tirto.id (verified administrative and factual by Press Council on 06-08-2019), liputan6.com (administrative and factual verified by the Press Council on 04-09-2018), tribunnews.com (administrative and factual verified by the Press Council on 04-09-2018), katadata.co.id (administrative and factual verified by the Press Council on 10-01-2019), beritasatu.com (administrative and factual verified by the Press Council on 18-11-2020), kontan.co.id (verified administrative and factual by the Per s on 15-07-2019), viva.co.id (administrative and factual verified by the Press Council on 04-092018).

The data collection technique used by researchers related to the Jokowi administration's repressive political communication was document study. In theory, Denzin (1979) has suggested that diary documents can also be a source of research data. The technical step for data collection is to select, record, collect data (can be downloaded or other data collection efforts) which are considered repressive legal products (regulations or laws). Repressive legal products (regulations or laws) can be in the form of laws, perppu, and Joint Decree (SKB).

The inductive method was chosen as a technique for analyzing data on the repressive political communication of the Jokowi administration. The inductive method will move from specific facts to general themes and the researcher makes interpretations of the meaning of the data (Creswell 2018). The data that has been collected as a product of repressive laws (regulations or legislation) is material to support the answers to the researcher's questions about what is the product of the Jokowi administration's repressive law and why the Jokowi administration issued the repressive legal product. At this stage, it is possible to do data disposal which is deemed irrelevant and add newly discovered data which according to the researcher becomes additional data to strengthen the answers to the research questions. 


\section{RESULTS AND DISCUSSION}

Disbandment of Ormas with the Law of the Republic of Indonesia Number 16 of 2017 and Joint Decree (SKB). Since President Joko Widodo issued Government Regulation in Lieu of Law (Perppu) Number 2 of 2017 concerning Amendments to Law Number 17 of 2013 concerning Community Organizations (Ormas) on July 10, 2017, polemics have been unavoidable. Many consider this a form of democratic harm (Riadi, Drajat, and Ulhaq 2018). With this Perppu, the government no longer needs to follow the court process which will take around 45 months to dissolve social organizations. The dominant role of the government without going through the courts is against Pancasila and can undermine democracy and encourage the government to act authoritatively. The Ormas Perppu has been used to disband Hizbut Tahrir Indonesia (HTI). Apart from using the Perppu Ormas, the government also uses The Joint Decree (SKB) of ministries and state agencies to dissolve the Islamic Defenders Front (FPI).

The dissolution of Hizbut Tahrir Indonesia (HTI). Less than two weeks after Perppu No.2 / 2017 was issued on July 10, 2017, the government revoked the legal status of Hizbut Tahrir Indonesia (HTI). The legal basis used is the Decree of the Minister of Law and Human Rights (SK Menkumham) Number AHU-30.AH.01.08 of 2017 concerning the Revocation of the Decree of the Minister of Law and Human Rights and the Decree of the Menkumham Number AHU-0028.60.10.2014 concerning the Ratification of the Establishment of Legal Entities for HTI Associations. With the revocation of the HTI Legal Entity Decree, HTI organizations were declared to be dissolved in accordance with Perppu Number 2 of 2017 Article 80A.

Coordinating Minister for Political, Legal and Security Affairs (Menkopolhukam) General (retired) Wiranto explained three reasons for the government to dissolve HTI. First, in terms of national objectives, HTI does not play a positive role in being involved in the development process. Second, HTI has strong indications of carrying out activities that are contrary to Pancasila and the 1945 Constitution of the Republic of Indonesia as stipulated in Law Number 17 of 2013 concerning Ormas. Third, HTI activities have caused clashes in society that can threaten public security and order, and endanger the integrity of the Republic of Indonesia. The Perpu was finally passed into the Law of the Republic of Indonesia Number 16 of 2017 on November 22, 2017. 


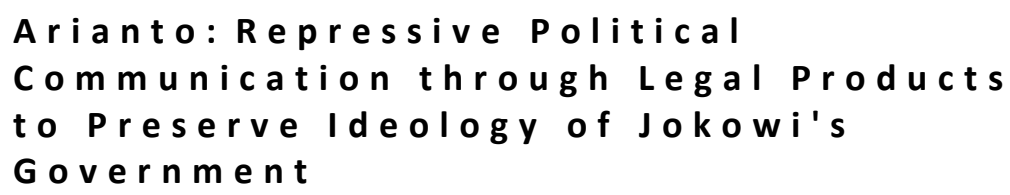

The government's assessment unilaterally without giving HTI the opportunity to test it in the judiciary so that HTI can make a defense is an action that injures freedom of opinion, assembly, and organization carried out by state apparatus with a tyrannical power approach. Even though the government does not yet have concrete guidelines on indicators that are used as a basis for stating that something violates and does not violate. Article 59 Paragraph 4 Letter C Perppu Ormas states that what is meant by teaching and understanding which is contrary to Pancasila is atheism, communism, Marxism / Leninism, or other ideas aimed at changing or changing Pancasila and the 1945 Constitution with the government.

Clear indicators of violating and contradicting Pancasila and the 1945 Constitution are indeed very crucial as an objective basis for evaluating all activities, policies, and behavior of citizens or mass organizations in Indonesia because the Indonesian state is indeed formed from many differences united by deliberation to reach a consensus. Historically, the Pancasila principles which are the philosophy of our nation are the result of a compromise by the founders of the nation, which consisted of religious groups and national groups. The seven words in the Jakarta Charter, which were initially approved by BPUPKI, are still being rejected by groups outside of Islam. Finally, through discussions between the founding fathers of the nation, the Islamic group gave up the seven words "Divinity with the obligation to carry out the Islamic law of its adherents" to be replaced with the only Godhead for the sake of national unity and integrity.

The government must carry out a due process of law (legal test) so that if there are Ormas deemed to be endangering the state, the government can file a trial. This has been agreed upon since 1999 as a check and balance concept so that no executive is too strong like during Orde Baru. The dissolution of mass organizations has been regulated in Law Number 17 of 2013 concerning Community Organizations. When the government indicates that a mass organization has committed a violation, the first step is to give a warning or warning sent by the government up to three times. Then there is the stage of stopping funding assistance, freezing the organization, and finally proceeding to 
court. The issuance of the Perppu has the potential to be used by the authorities as an instrument to repress groups that are hostile to the government.

The dissolution of the Islamic Defenders Front (FPI). FPI has been officially dissolved by the government based on Joint Decree (SKB) Number 220/4780 Year 2020, Number M.HH / 14.HH05.05 Year 2020, Number 690 Year 2020, Number 264 Year 2020, Number KB / 3 / XII Year 2020, and 320/2020 concerning the Prohibition of Activities to Use Symbols and Attributes and the Termination of FPI Activities. This SKB was signed by Minister of Home Affairs Tito Karnavian, Minister of Law and Human Rights Yasonna Laoly, Minister of Communication and Informatics (Menkominfo) Johnny G Plate, National Police Chief General Idham Azis, Attorney General ST Burhanuddin, and Head of the National Counterterrorism Agency (BNPT) Boy Rafly Amar (national.kompas.com, 2020).

The contents of the decree which was enacted on December 30, 2020, are: first, stating that the Islamic Defenders Front is an organization that is not registered as a social organization, as regulated in-laws and regulations so that it has de jure disbanded as a social organization. Second, FPI is a social organization that has de jure disbanded it continues to carry out activities that disturb the peace, public order, and are against the law. Third, prohibiting the carrying out of activities, the use of FPI symbols, and attributes in the jurisdiction of the Republic of Indonesia. Fourth, if there is a violation as regulated in the third dictum above, law enforcement officials will stop all activities carried out by FPI. Fifth, ask the public: a. To not be affected, engage in activities, use FPI symbols and attributes. b. To report to law enforcement officials any activity on the use of FPI symbols and attributes. Sixth, the ministries or agencies that sign this SKB are required to coordinate and take legal steps in accordance with statutory provisions. Seventh, this joint decree comes into force.

The dissolution of Ormas based on the SKB shows the repressiveness of the Jokowi government. Previously, when dissolving HTI, the government enacted Ormas Law Number 16 of 2017 as a substitute for Law Number 17 of 2013 to avoid a complicated legal process. The government succeeded in dissolving HTI by revising the Mass Organization Law through the Perppu. The dissolution of an Ormas should be consistent with the law that has just been enacted, but for FPI it uses an SKB. Referring to Law Number 16 of 2017 


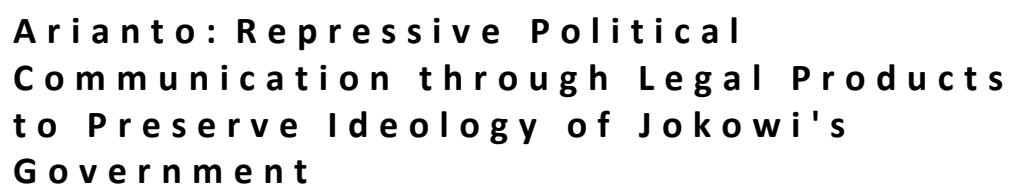

concerning Ormas, it requires a written warning for seven days. If within seven days the warning letter is ignored, it is followed by stage two, namely cessation of activities. After that, it can proceed with the revocation of legal entity status and dissolution.

The different choice of ways to disband the two Ormas shows that the government easily chooses the legal product it wants to repress Ormas, but the Ormas do not have the right to defend in court. This is of course a fundamental problem related to the rules on freedom of opinion, assembly and organization whose legal references both nationally and internationally are very clear. This type of repression has contributed to the decline in the Indonesian Democracy Index (IDI), which has been reflected in its decline since the beginning of Jokowi's administration.

Information and Electronic Transaction Law (UU ITE): Pressuring Opponents to Spoil Friends. Law Number 11 of 2008 concerning Electronic Information and Transactions and its amendments to Law Number 19 of 2016 have been widely used inappropriately by law enforcers. Indonesia's Southeast Asia Freedom of Expression Network (SAFENet) recorded 381 cases of the ITE Law 2011 s.d. 2019 which ensnares individuals and institutions. The website of the Supreme Court also informs that there were 508 cases in court that used the ITE Law during 2011 to. 2018. The largest case occurred in 2018, namely 292 cases, whereas in 2017 there were still 140 cases. The disputes throughout 2018 exceeded the total cases in 2011 s.d. 2017, namely 216 cases (tempo.co). SAFEnet noted articles frequently used by whistleblowers, namely Article 27 Paragraph (1) and Paragraph (3), Article 28 Paragraph (2), and Article 29 of the ITE Law. Most cases are crimes related to insult and defamation or defamation, Article 27 Paragraph 3 of the ITE Law. In second place is the case of hate speech Article 28 Paragraph 2 of the ITE Law. These two chapters have very flexible interpretations so that many people can easily become entangled.

The rubber article in the ITE Law is one of the causes which causes the rate of freedom of expression in Indonesia to continue to decline. The pattern of punishment under the ITE Law is usually in the form of: revenge, bartering cases, silencing criticism, shock therapy, and group persecution. The philosophy of the 
issuance of the ITE Law is actually a guarantee of legal certainty for electronic information and transactions, but the empirical reality actually threatens and has the potential to suppress freedom of expression. Not infrequently, this law is also used as a political weapon to overthrow opponents and protect friends. This can be seen from the high number of reported cases in political years.

The flexibility of the ITE Law benefits pro-government people because they are not prosecuted and even prosecuted when they violate the ITE Law.

Table 3.

List of Jokowi supporters \& their cases have been SP3 or not processed (processed from various online media sources from 2017 to 2020)

\begin{tabular}{|c|c|c|c|c|}
\hline No & Nama & Materi & Status & Tahun \\
\hline 1 & Fiktor Laiskodat & SARA tentang khilafah & SP3 & 2017 \\
\hline & Kaesang & Penodaan agama \& ujaran & Tidak & \\
\hline 2 & Pangarep & kebencian & diproses & 2017 \\
\hline & & $\begin{array}{l}\text { Ancaman membunuh Fadli Zon, } \\
\text { Fahira Idris, Rizieq Shihab, Buni }\end{array}$ & Tidak & \\
\hline 3 & Nathan Suwanto & Yani & diproses & 2017 \\
\hline 4 & $\begin{array}{l}\text { Ulin Yusron } \\
\text { Tabloid }\end{array}$ & $\begin{array}{l}\text { Penyebaran data pribadi orang lain } \\
\text { tanpa izin }\end{array}$ & $\begin{array}{l}\text { Tidak } \\
\text { diproses }\end{array}$ & 2019 \\
\hline & Indonesia & & Tidak & \\
\hline 5 & Barokah & Menyudutkan Prabowo- Sandi & diproses & 2019 \\
\hline 6 & Deny Siregar & $\begin{array}{l}\text { Penghinaan, SARA, pencemaran } \\
\text { nama baik (santri sebagai calon } \\
\text { teroris) }\end{array}$ & $\begin{array}{l}\text { Tidak } \\
\text { diproses }\end{array}$ & 2020 \\
\hline 7 & $\begin{array}{l}\text { Peretas WA } \\
\text { Ravio Patra }\end{array}$ & $\begin{array}{l}\text { meretas WA Ravio Patra dan } \\
\text { membuat postingan hasutan untuk } \\
\text { menjarah }\end{array}$ & $\begin{array}{l}\text { Tidak } \\
\text { diproses }\end{array}$ & 2020 \\
\hline
\end{tabular}

Different legal treatment is obtained if the violation of the ITE Law is a group that is at odds with the Jokowi administration. From 2016 to 2020, many have been arrested by the police, examined, become suspects, and even been sentenced to prison. The repression was getting bigger during the 2019 presidential election. 


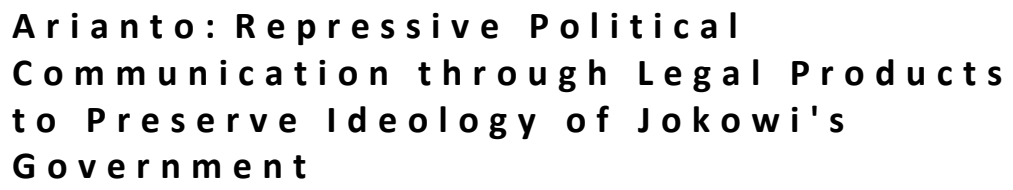

Table 4.

List of opponents of Jokowi's administration and supporters (compiled from various online media sources, 2016 to 2020)

\begin{tabular}{|c|c|c|c|c|}
\hline No & Nama & Materi & Konsekuensi & Tahun \\
\hline 1 & Obby Kogoya & Aksi Demo Papua & Kekerasan fisik & 2016 \\
\hline 2 & Ropi Yatsman & Menghina Jokowi (edit foto) & 15 bulan penjara & 2017 \\
\hline 3 & Rocky Gerung & kitab suci fiksi \& hoaks & Diperiksa & 2018 \\
\hline 4 & Said Didu & $\begin{array}{l}\text { Kritik pembelian saham } \\
\text { Freport }\end{array}$ & Copot jabatan & 2018 \\
\hline 5 & Refly Harun & Mengkritik kebijakan Jokowi & Copot jabatan & 2018 \\
\hline & & & Copot jabatan & 2020 \\
\hline & Neno & & & \\
\hline 6 & Warisman & \#2019gantipresiden & Ditangkap & 2018 \\
\hline 7 & $\begin{array}{l}\text { MFB (Ringgo) } \\
\text { Dandhy Dwi }\end{array}$ & Hina Jokowi dan Kapolri & $\begin{array}{l}18 \text { bulan penjara } \\
\text { Ditangkap dan }\end{array}$ & 2018 \\
\hline 8 & $\begin{array}{l}\text { Laksono } \\
\text { Ananda }\end{array}$ & Twitt kerusuhan Papua & tersangka & 2019 \\
\hline 9 & $\begin{array}{l}\text { Badudu } \\
\text { Lieus }\end{array}$ & Transfer uang demo Papua & $\begin{array}{l}\text { Ditangkap } \\
\text { Tersangka dan }\end{array}$ & 2019 \\
\hline 10 & $\begin{array}{l}\text { Sungkharisma } \\
\text { Darwin Fatih \& }\end{array}$ & Berita bohong dan makar & ditahan & 2019 \\
\hline 11 & Ipul & Meliput Demo & Kekerasan fisik & 2019 \\
\hline 12 & Ahmad Dani & Menghina Jokowi & 1 tahun penjara & 2019 \\
\hline 13 & Permadi & Kata-kata revolusi & $\begin{array}{l}\text { Diperiksa } \\
\text { Tersangka dan }\end{array}$ & 2019 \\
\hline 14 & Kivlan Zein & Makar \& senjata illegal & ditahan & 2019 \\
\hline 15 & $\begin{array}{l}\text { Adityawarman } \\
\text { Ratna }\end{array}$ & Kasus makar & Tersangka & 2019 \\
\hline 16 & Sarumpaet & Kasus makar & Tersangka & 2019 \\
\hline 17 & Firza Huzein & Kasus makar & Tersangka & 2019 \\
\hline 18 & Eko & Kasus makar & Tersangka & 2019 \\
\hline 19 & Alvin Indra & Kasus makar & Tersangka & 2019 \\
\hline 20 & Rachmawati S & Kasus makar & Tersangka & 2019 \\
\hline 21 & Sri Bintang P & Kasus makar & $\begin{array}{l}\text { Tersangka } \\
\text { Tersangka dan }\end{array}$ & 2019 \\
\hline 22 & $\begin{array}{l}\text { Eggy Sudjana } \\
\text { Muh Sofyan }\end{array}$ & $\begin{array}{l}\text { Kasus makar (people power) } \\
\text { Kasus makar dan berita }\end{array}$ & ditahan & 2019 \\
\hline 23 & Jacob & bohong & $\begin{array}{l}\text { Tersangka } \\
\text { Tersangka dan }\end{array}$ & 2019 \\
\hline 24 & $\begin{array}{l}\text { Soenarko } \\
\text { Hermawan }\end{array}$ & $\begin{array}{l}\text { Senjata ilegal dan makar } \\
\text { Ancaman memenggal }\end{array}$ & $\begin{array}{l}\text { ditahan } \\
\text { Tersangka dan }\end{array}$ & 2019 \\
\hline 25 & Susanto & $\begin{array}{l}\text { Jokowi) } \\
\text { Pembobol data pribadi Deny }\end{array}$ & $\begin{array}{l}\text { ditahan } \\
\text { Tersangka dan }\end{array}$ & 2019 \\
\hline 26 & FPH & Siregar & ditahan & 2020 \\
\hline
\end{tabular}


27 Ravio Patra

Moh Hisbun

28 Payu
Penghasutan penjarahan

Ujaran kebencian
Ditangkap polisi

Ditangkap dan

ditahan

All of the data mentioned above are of the same type as those carried out by groups that criticize the government, but, unfortunately, there are differences in handling treatment in the realm of law. For groups that are anti-Jokowi's government, the process runs fast and the police are proactive, while in the case of community groups who are pro-Jokowi's government, the legal process is slow, runs in place, even the legal process does not continue.

From the two tables above, it can be seen that there are differences in the treatment of the government or law enforcement agencies on cases committed by groups critical of Jokowi's administration and groups that are pro-Jokowi's administration. If the report is against a government critic, the police will immediately proceed to imprisonment. Meanwhile, reports on the pro-government group, the police were not processed or SP3-issued. Yet if we look at the values of Pancasila, civil society that is not given the mandate to hold power must get maximum service and protection in the legal process.

The new government was moved to revise the ITE Law again Monday, February 15, 2021 when President Jokowi said that he would invite the DPR to revise the ITE Law if the Law did not provide a sense of public justice. A revision took place in 2016 with the same premise that the ITE Law did contain a rubber article that could be abused. Even though it had claimed many victims, the government through the Minister of Communication and Information at that time with Minister Rudiantara did not delete Articles 27, 28, and 29 during the process of revising the ITE Law in the DPR.

Now, following up on the president's request, a Decree of the Coordinating Minister for Political, Legal and Security Affairs Number 22 of 2021 concerning the ITE Law Review Team has been issued. The study team involved three ministries, namely the Coordinating Ministry for Political, Legal and Security Affairs, the Ministry of Communication and Information Technology, and the Ministry of Law and Human Rights. The first team was tasked with discussing the guidelines for implementing the ITE Law so that it did not become a law with rubber articles that could be used to criminalize critical communities. The second 


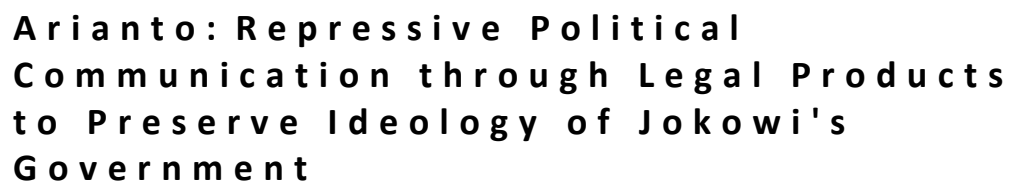

team was assigned the task of preparing revisions of several articles which were considered multiple interpretations (national.kompas.com, March 4, 2021).

The Minister of Communication and Information, Johnny G Plate, explained that one of the principles in the review of the revision of the ITE Law was to maintain and improve the quality of democracy, the quality of press freedom, the quality of association, the quality of assembly, and the quality of expressing opinions (KompasTekno, Monday (22/2/2021). Deputy Minister of Law and Human Rights Edward Omar Sharif Hiariej assessed that articles 27, 28, and 29 of Law Number 19 of 2016 concerning ITE are multi-interpretive articles and do not meet legality requirements due to the absence of clear and strict statutory rules (national.kompas.com, March 4, 2021).

National Police Chief Listyo Sigit also followed up on the president's direction by issuing a telegram numbered ST / 339 / II / RES.1.1.1. / 2021 dated February 22, 2021 signed by Deputy Head of Criminal Investigation, Inspector General Wahyu Hadiningrat on behalf of the National Police Chief (kompas.com, 23 Feb 2021). Polri classifies cases under the ITE Law with two different settlement approaches. First, criminal acts that can be resolved by means of restorative justice or restorative justice, namely, defamation, slander, or insult, the handling is based on Article 27 paragraph (3) of the ITE Law and Article 207 of the Criminal Code by not detaining.

The second approach is criminal acts that have the potential to divide the nation (disintegration and intolerance), namely crimes that contain elements of SARA, hatred against groups or religions and racial and ethnic discrimination. The handling is guided by Article 28 paragraph (2) of the ITE Law, Article 156 of the Criminal Code, Article 156a of the Criminal Code, and Article 4 of Law Number 40 of 2008. Then, the spread of fake news that causes confusion, the handling refers to Article 14 Paragraph (1) of Law Number 1 Year 1946. In addition, the National Police Chief instructed that case titles be carried out virtually through zoom meetings to the Head of Criminal Investigation and Dirtipidsiber at each stage of investigation and determination of suspects. The National Police Chief also issued a policy of having a virtual police officer to 
monitor social media and give warnings if there is content categorized as violating the ITE Law.

Researchers assess that the Jokowi administration's move to roll back the discourse on the revision of the ITE Law is the right step even though it is too late. At the time of the revision in 2016, articles 27, 28, and 29 should have been improved so that critical communities do not become victims of criminalization. Until 2021, the omission has lasted 4 years. During that time, there have been many unnecessary casualties from society. Moreover, in its implementation in the realm of law, the ITE Law is more used to suppress opponents and save friends. That condition is sufficient to provide positive incentives for power and supporters to continue to protect their power and be able to win political contestation in 2019. Then after Jokowi won the political contestation so that he could become president for the second term and according to the rule of law is the last term, the new president showed his seriousness to improve the articles - the rubber article.

Decree on Handling Radicalism. The Joint Decree (SKB) of six ministries and five state institutions related to the handling of radicalism in the state civil apparatus (ASN) was issued on November 12, 2019. The ministers and heads of agencies involved are the Minister for Administrative Reform and Bureaucratic Reform Tjahjo Kumolo, Minister of Home Affairs Tito Karnavian, Minister of Law and Human Rights Yasonna Laoly, Minister of Religion Fachrul Razi, Minister of Education and Culture Nadiem Anwar Makarim, and Minister of Communication and Information Johnny G. Plate, Head of State Intelligence Agency Budi Gunawan, Head of the National Counterterrorism Agency Suhardi Alius, Head of the Civil Service Agency Negara Bima Haria Wibisana, Acting Head of the Pancasila Ideology Development Agency Hariyono, and Chairman of the ASN Commission Agus Pramusinto.

The polemic that has been criticized by many community groups is the fifth point of the decree which contains 11 types of violations, namely:

1. Delivering opinions both orally and in writing in text, image, audio, or video formats, through social media that contain hate speech against Pancasila, UUD 1945, Bhinneka Tunggal Ika, NKRI, and the Government; 


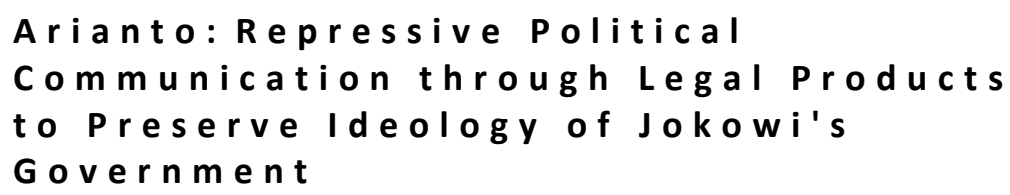

2. Delivering opinions both orally and in writing in the format of text, images, audio, or video, through social media that contains hate speech against one ethnic group, religion, race, and between groups;

3. Dissemination of hate speech as numbers 1 and 2 through social media (share, broadcast, upload, retweet, repost, and the like);

4. Feedback or support as a sign of agreeing to the opinion as referred to in numbers 1 and 2 by giving likes, dislikes, loves, retweets, or comments on social media;

5. Misleading reporting either directly or through social media;

6. Dissemination of misleading news either directly or through social media;

7. Organizing activities that lead to acts of insulting, inciting, provoking, and hating Pancasila, UUD 1945, Bhinneka Tunggal Ika, NKRI, and the Government;

8. Participation in organizations and / or activities that are believed to lead to acts of insulting, inciting, provoking, and hating Pancasila, UUD 1945, Bhinneka Tunggal Ika, NKRI, and the Government;

9. The use of attributes that are contrary to Pancasila, the 1945 Constitution, Bhinneka Tunggal Ika, NKRI, and the Government;

10. Harassment of state symbols either directly or through social media;

11. Actions as referred to in numbers 1 to 10 are carried out consciously by ASN.

The eleven ASN violations referred to in the SKB above can be submitted to the aduanasn.id portal. The government through Cabinet Secretary Pramono Anung denied that the government was considered allergic to criticism following the issuance of Joint Decree (SKB) for 11 government agencies. Pramono explained that the government through the SKB wanted people not to consume hate speech in their daily lives. Pramono also asked the public to distinguish between criticism and hate speech.

Many activist groups for human rights, law and civil liberties have criticized the issuance of the SKB 11 for this government agency. There is the Chairperson of the Advocacy Division of the Indonesian Legal Aid Foundation (YLBHI) Muhammad Isnur, Lokataru Foundation Founder Haris Azhar, Executive Director of Amnesty International Indonesia Usman Hamid, and 
Komnas HAM Commissioner Choirul Anam who assessed the Joint Decree (SKB) on handling radicalism in the State Civil Apparatus (ASN) has the opportunity to violate the right to freedom of opinion and expression because the decree does not have clear indicators and definitions of radicalism so that it is prone to be used by the authorities to silence critical communities. The authority of existing institutions such as the Ombudsman, inspectorates in ministries / agencies, or the ASN Commission should be maximized. Apart from maximizing the role of existing institutions, a more comprehensive definition is also needed as a clear basis for hate speech.

Actually, the government does not need to issue a decree on handling radicalism in ASN because:

1. With regard to hate speech, the government already has Article 28 Paragraph 2 of the ITE Law on hate speech (although like the previous discussion, researchers also note that the implementation of the ITE Law by law enforcement officials still tends to be used to suppress groups that are opposed to the government). The government should concentrate on improving the content of the ITE Law if it is deemed not comprehensive. The government should pay attention to this overlap of regulations so that legal products in Indonesia are simpler, more efficient, and more credible. The existence of quality legal products in terms of political communication will also increase the authority of government personnel.

2. Regarding supervision, the government actually already has institutions that can enforce thisbut. Maximizing the inspectorate in each ministry, the ASN Commission, and the Ombusman must be prioritized by the government rather than building a new system which is actually the task of an existing institution. If it is felt that an existing institution is not functioning properly, there must be an evaluation of the institution so that it can be decided whether the institution needs to be dissolved or can still be repaired. Determining the benchmarks for the success of a supervisory institution is important from the point of view of government political communication so that the public also understands that an institution that is paid from public money is functioning optimally or not.

3. Government personnel in a democracy are designed to be evaluated. This means of evaluation has been provided with elections every five years or 


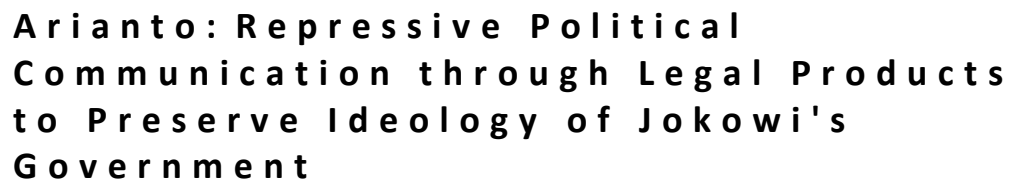

supervision through the people's representative council. Therefore, government personnel must build a credible evaluative political communication system so that the public is channeled properly if they experience dissatisfaction with government performance. The political elite (executive) oligarchy with the leadership of political parties (which ultimately affects the performance of political parties in the DPR) coupled with the media oligarchy supporting the government have made democratic values not run well. If the government protects itself with legal products made by itself to justify its political steps and build distance from the people, of course this is a step backwards from a democratic government system.

Omnibus Law on Job Creation Bill. The discourse of the Omnibus Law as a leap for the legal revolution was first conveyed by President Jokowi in his inauguration speech as president of the Republic of Indonesia for his second term, 2019-2024. Jokowi emphasized that overlapping regulations, convoluted bureaucracy, and a large number of illegal fees were the main obstacles to investment. In short, corruption hinders investment. The Omnibus Law is also often referred to as the global sweep law which has the aim of simplifying regulatory constraints that are currently complicated and long.

Constitutional Law Expert Bivitri Savitri explained that the Omnibus Law is a law designed to target major issues in a country by revoking or amending several laws. This law is intended to streamline regulation in terms of numbers. This step is in line with Jokowi's developmental type of leadership (Warburton 2016). Jokowi will focus on achieving rapid economic growth and tend to ignore or eliminate the inhibiting factors. The omnibus law was made to facilitate foreign investment, which has been experiencing difficulties related to licensing that is complicated, numerous, and long. Jokowi and his economic team firmly believe that attracting foreign investors to Indonesia is the fastest way to increase national economic growth.

There are at least 82 laws and 1,194 articles that will be harmonized with the Omnibus Law. The substance of this bill consists of eleven problem clusters involving 31 ministries / agencies. The eleven clusters referred to in the Job Creation Bill are: 1. Simplified land permits 2. Investment requirements 3. 
Employment 4. Ease and protection for MSMEs 5. Ease of doing business 6 . Research and innovation support 7. Government administration 8. Imposition of sanctions 9. Control land 10. Ease of government projects 11. Special Economic Zones (KEK).

The government's move, which wants to move quickly to complete the Omnibus Law Work Creation Law without opening dialogue and giving space to various key stakeholders, seems to be a hassle for the government and creates a negative stigma that the government is running a closed, authoritarian and collusive elite state system. for the issue of polity (the interest of the masses), the government should have opened up discursive space (Nugroho 2017). Initially, the process of drafting the Omnibus Law Bill which was closed with the work team was dominated by entrepreneurs without involving any element of labor. After being busy in the public, three large labor unions suddenly joined the draft review team. Even though the labor union firmly rejects the regulation which is considered to be detrimental to the workers.

Several labor unions that have joined the Omnibus Law technical team formed by the Minister of Manpower decided to leave the team (tempo. co, 2020). KSPI President Said Iqbal stated that KSPI and several labor unions had left the team. The team was formed to discuss the labor cluster in the Job Creation Bill which was rejected by the workers, but the labor union group was disappointed because its recommendations were not accommodated in the revision of the draft bill. Worried that they would only be used as government legitimacy that workers had participated in the discussion even though the recommendations were not accommodated, the labor group chose to leave the team.

Some labor losses due to the Job Creation Law include: first, the city or district minimum wage is in danger of being lost. Article $88 \mathrm{C}$ of the draft bill states that the governor sets the minimum wage as a safety net. Paragraph 2 further explains that the minimum wage as mentioned above is the provincial minimum wage (UMP). In other words, this rule allows a wage scheme by eliminating the district or city minimum wage (UMK), district or city sectoral minimum wages (UMSK), and making the UMP the only reference for the amount of the salary value. This will certainly be detrimental to workers who have been referring to the UMK which is already higher than the UMP. 


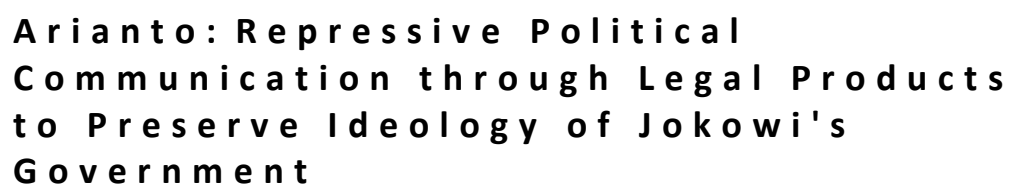

Second, the amount of layoff severance is reduced. The government reduces the amount of severance pay that employers must pay if they terminate their employment (PHK). Third, remove menstrual leave for women. The Work Creation Bill (RUU Cipta Kerja) amends several special leave provisions or permits listed in Law Number 13 of 2003 concerning Manpower. Among the changes are removing special leave or absence permits during the first day of menstruation for women. In the Manpower Law, this rule is stated in Article 93 letter A. In addition, this broomstick bill also removes special permits or leave for marrying, marrying, circumcising, baptizing their children, giving birth/miscarriage, to family members in one house who died (letter B).

Fourth, the fate of outsourcing is increasingly unclear. The Omnibus Law removes Articles 64 and 65 of the Manpower Law that previously regulated agency workers. Article 64 of the Manpower Law reads; Companies can hand over part of the implementation of workers to other companies through a written agreement for the provision of worker / labor services. Furthermore, Article 65 regulates; (1) Submission of part of the work implementation to another company is carried out through a written agreement for work contracting. Paragraph (2) regulates; (2) the work that can be submitted to another company as meant in paragraph (1) must meet the following requirements: carried out separately from the main activity; carried out by direct or indirect orders from the employer; is a company supporting activity as a whole; and does not directly hinder the production process.

Fifth, workers can be contracted for life. The Job Creation Bill will provide space for employers to contract a worker or laborer indefinitely. This Job Creation Bill will remove the provisions of Article 59 of Law Number 13 of 2003 concerning Manpower. This article regulates the rules for a Specific Time Work Agreement (PKWT). Among them, it contains provisions that PKWT can only be carried out for a maximum of two years and can only be extended once for a maximum period of one year.

Workers are restless because the philosophy of the Job Creation Law makes it easier for foreign investors to invest in Indonesia in droves. For this purpose, the government has made it easier for foreign workers to work permits, 
permits that have been hindering because they have been accelerated, trimmed, and modified for a long time. Labor issues that have been troubling investors, such as labor wages, severance pay, and employment status, are proposed to be changed. The entrepreneur represented by Rosan Roeslani said that in the Omnibus Law proposal, the entrepreneur would be spared from criminal sanctions, but it was enough to pay a fine or settle it civilly. In addition, the law includes a licensing package that no longer needs an IMB and Amdal.

The plan to simplify or even remove building permits (IMB) and environmental impact analysis (Amdal) which are part of the Omnibus Law Bill on investment also shows the paradox of Jokowi's speech at the inauguration. On the one hand, the design shows the spirit of market reform by creating investment convenience, but on the other hand, the plan to simplify or eliminate business licensing instruments is contradictory to market interests that rest on transparency and accountability.

Changing the Amdal with a detailed spatial plan (RDTR) document, as stated by the Ministry of ATR / BPN, is tantamount to transferring responsibility for managing environmental impacts from corporations to local governments. This of course makes it easier for entrepreneurs, but burdens the local government. Meanwhile, out of 514 districts / cities, only 40 regions have RDTR documents. To overcome the slow pace of regional governments in preparing the document, the Omnibus Law Bill provides an opportunity for the central government to take over the granting of business licenses, even to issue the RDTR document.

The domination of the central government can of course lead back to the centralization that the reformers have rejected. The current government also often refers to authoritarian countries such as China, Singapore, and Vietnam as examples of how to improve the business climate to increase investor attractiveness. Businessmen tend to yearn for a non-democratic political climate because democracy slows down business decisions that should be taken quickly. Economic actors in Indonesia, who are still dominated by the old faces of national entrepreneurs, are not only able to adapt to a corrupt environment but can also exploit that environment to maximize profits. Employers admit that the barriers to investment are burdensome tax laws and expensive labor that is difficult to fire. The government's statement that bureaucracy is complicated and corruption is a 


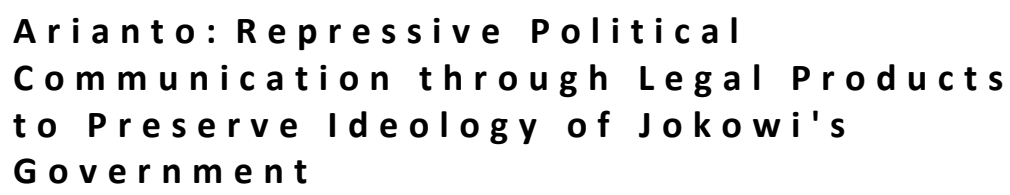

barrier to investment is an excuse to divert public attention to efforts to change labor regulations that are considered burdensome. The government and the business world want to make a labor supply that is cheap and easy to regulate and dismiss, not on the presence or absence of accountability and transparency in the business world.

The huge public pressure on the government related to the Omnibus Law on the Job Creation Bill made the government pay influncers to win public opinion. A total of 21 artists and celebrities uploaded content and hashtags \#indonesiabutuhkerja (tempo.co, 2010). There are Ardhito Pramono, Gofar Hilman, Aditya Fadilla, Gading Martin, Gisella Anastasia, Valentino Simanjuntak, Cita Citata, Rigen Rakelna, Boris Bokir, Ar uan Marsha, Kim Kurniawan, Siti Badriah, Gritte Agatha, and Fitri Tropica. Ardhito said he was contacted and paid by a public relations worker named Fendy Angger Alam, worth Rp. 10 million for each tweet. Fendy Angger works as a public relations officer at PT Mahaka Radio Integra Tbk. The company, which is engaged in investment, consulting services, and digital media, was started by the Minister for State-Owned Enterprises, Erick Thohir. After it was finally discovered that the hashtag was connected to the Omnibus Law Bill, Ardhito Pramono and Aditya Fadilla admitted that they would return the money.

Regarding influencers, Executive Director of Communications, Hariqo Wibawa Satria, said that the government often uses contractors or third parties to manage social media. He assessed that this phenomenon occurred due to the slow pace of government organizations in preparing structures to keep up with digital change (tempo.co, 2020). The government and the apparatus under it want instant work by paying social media managers or influencers. Indonesia Corruption Watch (ICW) noted that the central government disbursed funds worth Rp. 90.45 billion to pay for influencers whose use was spread across various ministries (kompas.com, 2020). The data was collected through the Electronic Procurement Service (LPSE) on August 14-18, 2020.

Researchers consider that the government is repressive in producing legal products due to the government's rush to complete the Job Creation Law and ignores protests from affected community groups, especially workers. It does not 
stop there, to seek legitimacy from the community, the government responds to criticism by paying influencers who have many followers in the hope of winning opinions in the media and constructing society to support the Job Creation Law. Of course, these are typically practical steps to win public opinion in this digital era. The government has been trapped in winning the narrative quantitatively and ignoring the quality of public dialogue in responding to legal products concerning crucial public issues.

\section{CONCLUSION}

The Jokowi administration's repressive political communication through legal products is an attempt to maintain power and smooth out the neoliberal capitalist economic ideology. According to (Power 2018), the repressive actions carried out by Jokowi are in the authoritarian category because they use the power of state institutions, especially law enforcement instruments, for the benefit of power groups and the suppression of legitimate democratic constitutional rights. Opposition Efforts to maintain power can be seen by maximizing the use of the ITE Law which pressures opponents and spoils friends. Meanwhile, ideological refinement is carried out through the Omnibus Law Cipta Kerja legal product which is closed and in favor of foreign investment and the market. The repressive legal products of the Jokowi administration are contrary to the fundamental values of democracy, namely civil liberties in having an opinion, assembly and organization. The repressive politics of legal products are of course contrary to the fundamental values of democracy, especially civil liberties in speaking, assembling and organizing.

\section{REFERENCES}

Barata, Mariam Fatima and Melvin Bonardo Simanjuntak. 2019. "STRATEGI PUBLISITAS \& PROPAGANDA POLITIK (Studi Pada Kandidat Presiden \& Wakil Presiden, Jokowi-KH. Ma'ruf Amin)." Jurnal Studi Komunikasi Dan Media 23(2):135.

Creswell, John W. dan J. David Creswell. 2018. Research Desain; Qualitative, Quantitative and Mixed Methods Approaches. Vol. 53. Fifth. 


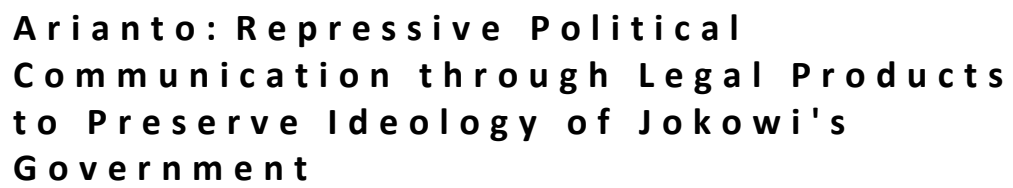

Davenport, Christian. 1995. "Multi-Dimensional Threat Perception and State Repression: An Inquiry into Why States Apply Negative Sanctions." American Journal of Political Science 39(3):683.

Davenport, Christian. 2007. "State Repression and Political Order." Annual Review of Political Science 10:1-23.

van Dijk, Teun A. 1997. "What Is Political Discourse Analysis?” Belgian Journal of Linguistics 11:11-52.

Dijk, Teun A. van. 2011. "Ideology and Discourse. A Multidisciplinary Introduction." Pompeu Fobra University, Barcelona.

Fakih, Farabi. 1981. Authoritarian Modernization in Indonesia's Early Independence Period The Foundation of the New Order State (19501965). Leiden: Brill.

Fauzi, Agus Machfud. 2018. "Jokowi’s Political Branding for the Victory of the President." Advanced Science Letters 23(12):11674-77.

Ferazia, Intan, Prayudi Prayudi, and Subhan Afifi. 2020. "Analysis of Communication Networks among Political Elites in the Formation of Party Coalitions.” Jurnal Ilmu Komunikasi 18(1):95.

Hamid, Abdul. 2014. "Jokowi's Populism in the 2012 Jakarta Gubernatorial Election.” Journal of Current Southeast Asian Affairs 33(1):85-109.

Lillaker, Darren G. 2006. Key Concepts in Political Communication. London: Sage Publications.

Mietzner, Marcus. 2015. "Jokowi's Challenge: The Structural Problems of Governance in Democratic Indonesia." Governance 28(1):1-3.

Møller, Jørgen and Svend Erik Skaaning. 2013. "Autocracies, Democracies, and the Violation of Civil Liberties." Democratization 20(1):82-106.

Muhtadi, Burhanuddin. 2015. "Jokowi's First Year: A Weak President Caught between Reform and Oligarchic Politics." Bulletin of Indonesian Economic Studies 51(3):349-68.

Nugroho, Ari Cahyo. 2017. “Aspirasi Publik Bidang Kominfo Eksistensi Komisi Informasi Daerah Di Wilayah Jambi, Bengkulu, Bangka Belitung Dan DKI Jakarta.” Jurnal Studi Komunikasi Dan Media 21(2):181-92. 
Power, Thomas P. 2018. "Jokowi's Authoritarian Turn and Indonesia's Democratic Decline.” Bulletin of Indonesian Economic Studies 54(3):30738.

Repucci, Sarah. 2020. "Freedom in the World 2020 A Leaderless Struggle for Democracy."

Riadi, Bagus, Diki Drajat, and M. Zia Ulhaq. 2018. "Analisis Kebijakan Perppu Ormas: Kritik Terhadap Perppu Nomor 2 Tahun 2017.” (January).

Tyson, Adam and Budi Purnomo. 2017. "President Jokowi and the 2014 Obor Rakyat Controversy in Indonesia." Critical Asian Studies 49(1):117-36.

Warburton, Eve. 2016. "Jokowi and the New Developmentalism." Bulletin of Indonesian Economic Studies 52(3):297-320.

Winters, Jeffrey A. 2013. "Oligarchy and Democracy in Indonesia." Indonesia 2013(96Special Issue):11-33.

Wodak, Ruth. 2009. "The Discourse of Politics in Action." The Discourse of Politics in Action. 